\title{
A study of the Relationship between Human Capital Accumulation and Economic Growth: A case of Liberia
}

Faliku S. Dukuly ( $\sim$ fsduke2@gmail.com )

Shanghai Maritime University https://orcid.org/0000-0003-3116-7690

Kun Huang

Shanghai Maritime University School of Economics and Management

\section{Research}

Keywords: Human Capital, Economic growth, Education, Health Expenditure, Liberia

Posted Date: January 7th, 2021

DOI: https://doi.org/10.21203/rs.3.rs-139365/v1

License: (c) (1) This work is licensed under a Creative Commons Attribution 4.0 International License.

Read Full License 


\section{Introduction}

The observed link between human capital and economic growth is incontrovertible. The association between human capital and the growth of the economy can be affected either directly or indirectly through the influence of education that can serve as an important element in both accumulating human capital and increasing national wealth.

There is a large body of empirical literature that has revealed that one of the most effective means that drive economic growth for countries is the inclusion and the progress of human capital Pelinescua (2014), Riley G. (2012), G, D, and Weil D. N (1992). De La Fuente A. (2000) argued about the effect of the level (so-called level effect) on its influence on production through labor productivity is advantageous. This effect can also be seen after the increased in competitive advantage due to innovation factors, or the spread of technology (Pistorius, 2004), (Siggel, 2000), and (Horwitz, 2005).

Economists have used theories and empirical research to explain the causal factors that account for economic growth among countries. Among these are people like Professor Robert Solow (Solow-Swan model) providing theoretical backings and arguments to support these growth theories and hypotheses. These empirical works that specifically look into factors that determine growth in developing economies are our best tool to help us understand and solve our problems.

The technological breakthrough in the last few decades has also paved the way to revolutionize the how countries handle their economy. When considering human capital, we can say that the success of individuals depends on their higher level of competency in a society. It means that people are becoming more and more educated and also becoming valuable assets in their countries. From an economic viewpoint, capital refers to the factors of production used to create goods or services. While the human component is the subject to take charge of those economic activities such as production factors, consumption, and transaction among people within the society.

Human capital through economic development plays a key role in the nation-building and rebuilding process and is one of the driven forces behind every economy while the topic remains predominant research focus on economics. According to Hadir (2015), human capital is the most valuable asset in both developed and developing countries. 
As poverty drives the lives of millions in Sub-Sahara African countries, and also other parts of the globe, many countries are still a reliance on foreign aid and remittances as a major source of revenue generation instead of investment and focusing on human capital development. It can be advantageous especially to those of the least developed and developing countries of Sub-Saharan African countries to aim at maximizing their capacity in spending on the component of human capital in boosting their economic growth as the population continues to swell yearly.

The lack of government spending adequately on citizens in Liberia through human capital investment has contributed to numerous challenges ranging from low living standard, poor quality of educational delivery in formal and informal intuitions of acquiring knowledge and skills consequently results in deprived and unequipped (workforce) graduates to weak infrastructures in healthcare delivery and other institutions. The situation in these regions generally is described as by their low levels of literacy rate, poor health care system, gender inequality, low standard of living, and low-income earning that many live on one meal a day. Furthermore, with low and often insufficient spending by the policymakers on the national health care system and public education, requisite infrastructure essential to improve human capital growth in developing countries remain very low and in a struggling stage.

Liberia as one of the poorest growing countries on the coast of West Africa, the low level of human capital resources has hindered the productivity level of individuals and results in a range of socio-economic challenges faced by both government and people ranging from poverty and unemployment in society have risen over time to a high level. In other to achieve steady/cutting-edge economic growth, a nation should have a well-educated and diversified workforce of healthy men and women trained to take over the day-to-day affairs of the economy. One way to achieve this by a government is to ensure that adequate investment is made to create a productive workforce of citizens at all levels.

People's value and their knowledge in society can turn out to be very rewarding when it starts to show up in their productivity and output, therefore, this component of development within the economy cannot be overlooked. The wealth of a nation does not only lie in its produced capital, natural resources, but it's in its people; their skills, their health, and their resilience to give back to society is determined by human capital. 
People, and their human capital capability, are fundamental long run and sustainable economic growth tools for life transformation. Over the last few decays, many prominent international organizations have placed more focus on human development, especially in Sub-Sahara African countries, and among them is the World Bank Development Group.

The World Bank's Africa Human Capital Plan identifies several game-changers in other to accelerate Africa's human development capacity. Not only that but also, the proposed European Union's 2020 Strategy/agenda that is centered around the building of human capital for economic growth while the same for the World Bank Development Group.

The EU's global goals set in 2015 aim at ending poverty, protect the planet, and ensure prosperity for everyone by 2030. In other to meet these deadlines and set criteria, for transformative and economic sustainability particularly for the least developed and third world countries in Africa and elsewhere, human capital or the knowledge and value of people cannot be overlooked in no time.

To empower women and young girls is the first key component. By doing, so will directly improve human capital and create a demographic change that will significantly impact poverty and human development and as well as fragility, climate, and inclusive economic growth on the continent of Africa. Second, preventing the loss of life in fragile and conflict settings, and also supporting displaced communities to increase human capital must be a major focus. Third, developing human capital requires multi-sectorial solutions that focus on transportation, affordable energy supply, good governance, and as well as interventions across other sectors like safe drinking water, agriculture, and food security.

It is also about social protection systems that provide help to the most vulnerable in society. Fourth, harnessing the opportunities that technology and innovation offer can improve the human capital outcomes and productivity in many other sectors. In general, Africa has growth potential at all levels that lie mainly in the continent's youthful population which gives it the edge among others for future growth opportunities but to achieve that, the continent needs to invest in human capital.

Liberia being one of the oldest African Republic and funded in 1847, still lacks the basic of social services for her people. The account for human capital and development in the West African Nation is still lacking. Despite the country has natural mineral resources, it still lacks the basis of human capital across all sectors. Women and children are the most venerable in 
Liberian society. For instant, the women population between the age group 15 years and above account for 912,725 illiterates in 2017 as compared to men 509,919. The gap between the sexes' male and female illiterate's rate is very high within the population and makes it even more difficult when accounting for human capital in the population. For example, to refer to the UNESCO 2017 figure on Liberia's adult literacy rate, about $48.3 \%$ is accounted for in the total population on adult literacy while the male literacy rate is $62.7 \%$, and females $34.1 \%$ between the age 15 years and older. Even though Liberia has a lower literacy rate as compared to some of her neighbors (Sierra Leone, Guinea, and Ivory Coast), with little disparity within the figures among these countries, there is still much more that needs to be done in narrowing these gaps.

Liberia's educational system is very weak and is still faced with many challenges in both private and public institutions. Due to poorly trained and uneven distribution of skilled workforce among teachers in the classroom, it makes it difficult for learners (school-age children) to acquire the skill they need. The same goes for the health care sectors where the wealthy ones among politicians have to seek healthcare abroad and leaving the system broken and poorly manage. This is what makes human capital more essential in achieving economic growth not only for Liberia but also across other regions. From this backdrop, we can say that this study will be significant to the government of Liberia and including those of other agencies for improving human capital and development. Apart from policymakers, this study will also serve as a tool to aid future researchers in serving as a guard while at the same time helping other interest groups.

Our proposed hypothesis to be tested is that investment in human capital through education (health care) has a long-run relationship with the labor-force and economic growth. Investing in people (the workforce) will grow over time and increased the growth rate in regions with low initial values and investment. To achieve the study goal, the author has employed a theoretical framework that is based on a Neo-Classical economic growth model using endogenous variables that has a link with economic growth. In highlight the role of human capital through education, and as a pathway to economic growth and development in Liberia, the study used a time series analysis on data general from the World Bank Development Indicators from the period 2000 to 2019. 


\section{Review of Current Literature (Economic Growth Theories and Human Capital Development Regime)}

The ideal concepts of economic growth and development are associated with economic output and economic progress for countries. From a microeconomics standpoint, the human capital theory suggests that education is an asset/investment that increases once productivity and income level (Neamtu, 2015). To find out whether this is effective, one could look at the increasing rate of the average incomes of people in the economy. Berger, N., and Fisher, P. (2013) also argued that in other to achieve rising incomes for average people, two things need to happen: productivity needs to increase (creating more income overall), and new income generated from their increased productivity needs to be returned to workers in the form of higher wages where he argued that a well-educated workforce is key a to state prosperity.

The link between aid and economic growth has been presented theoretically, and empirically in previous literature. There are channels through which foreign aid affects economic growth and these channels are accumulation; direct Growth; and Conditional theoretical models argued by Fashina (2018). The Accumulation model projected that the impacts of foreign aid are on either savings or investment, and showed that aid has an indistinct effect on the accumulation of capital/wealth. On the other hand, the direct Growth model framework used the reduced model of the effect of foreign aid on growth set considerably, and also combined to a positive, but do not have significant effects on growth itself according to Fashina.

The empirical analysis of (Luqman, 2014) used dynamic growth equations on a panel data approach for a set of nine Asian countries over the period 1972-2012. The overall evidence shows that foreign trade improves the accumulation of human capital and contributes to economic growth positively.

Acemoglu (2012), argued that there are several channels through which human capital may affect technological progress. In their argument, they stress that individuals with the highest talents may in some way contribute to the technological component and progress by the use of their human capital skills if they have the necessary access to education amenities. In that way, these individuals can have the utmost significant impact on technological progress. Apart from that, the workforce, in general, could affect technology, that is, due to the externalities derived from human capital and, also, because human capital alters and increases 
the incentives for people to invest more in technological advancement. For instance, the inclusion of the technological component of human capital is likely only advantageous and more profitable if there are enough and skilled workers who know how to use those pieces of machinery and tools to maximize output.

The pioneering work of Barro (1991), Romer (1993), and including Mankiw and David Wei (1992) demonstrated that the cross-country data can be read as consistent with either income non-convergence of convergence; and the extensive research over the intervening years has not produced a consensus (Jones, 1997), and (Pritchett, 1997). Economists have long started the importance of human capital in the process of growth. One might assume that neglecting human capital would lead to incorrect outcomes. Including human capital can potentially alter either theoretical modeling or the empirical analysis of economic growth which can be overlooked. Lucas (1988), for example, believes that although there are diminishing returns to physical-capital accumulation when human capital is held fixed, the returns to all reproducible capital (human plus physical) are constant.

Babini (1991) examined coefficients of variation for education variables for a sample of countries from 1960 to 1983. Since the coefficient of variation in the sample declined for enrollment rates at the three different levels of education contracted, therefore she concluded by saying that these indicators were converging. The research found the highest convergence at the primary level.

These individuals possess perhaps the most significant influence on technological advancement. Also, the workforce in more general terms may affect technology, that is, due to the externalities derived from human capital and, also, because human capital alters and increases the incentives to invest more in technological progress. Notwithstanding, technology may be only sufficiently profitable if there are enough skilled workers who know how to perform well on the job.

Long ago, the importance of human capital development was already considered in the early works of Adam Smith and Alfred Marshall see Demeulemeester (2011) and Hipper R. (2014). However, it took a considerable length of time for human capital to emerge as a key factor for economic growth and is now being discussed among economic technicians. The most important contributions were developed from the mid-20th century and onwards (Hippe C. D., 2019). For example, to be specific, (Becker, 1964). 
Is extensively acknowledged as a founder of human capital theory, underlining that human capital increases the productivity of workers. Elena P. (2015) study on "The Impact of Human Capital on Economic Growth" revealed a positive relationship between GDP per capita growth and innovative capacity of human capital (evidenced by the number of patents) and the qualification of employees (secondary education) as expected according to economic theory. In another development right about the beginning of the 1990s emerged new advancement in economics theory. An extension of Robert Solow's original growth model (i.e., the human-capital augmented Solow Growth model) was presented by Mankiw, Romer, and Weil (Mankiw, 1992). The model explicitly includes human capital as a factor in the Cobb-Douglas production function. Also, the endogenous growth model, another kind of growth model, was introduced by (Romer P. M., 1986) and (Lucas, 1988).

Historically, Robert Solow's pioneering work on economic growth in the 1950s led to the formulation of growth accounting and the discovery of the "residual" and it is certainly that portion of economic growth that the researcher cannot easily explain due to the increase in physical productive factors such as the capital stock, the number of workers, and their hours and weeks of work (Haupert, 2014).

The magnitude of the residual during much of the twentieth century relative to economic growth in per capita income or per worker terms demonstrated that physical capital accumulation did not explain much of growth phenomena and that something is responsible. That something else can be considered as knowledge import and the augmentation of the labor input through education and training of people. In other words, much of the residual was due to the increase in human capital formation. Some researchers have developed methods to close up or tighten the "residual" gap by adding human capital growth variables to the Solow neoclassical growth model (G, D, \& Weil D.N, 1992).

Among the most important findings regarding economic growth over the long run period, is the one most relevant to the study of human capital in history, that the residual has increased greatly over time. When people acquired certain knowledge or skills, it does not only help in the short run period but also, in the long run, it yields more output-on investment and return to skills.

In general, we conclude by saying that all these growth models consider human capital as a fundamental tool and a driving force for economic growth and development, especially in 
the long run. Ultimately, the newest contribution to the field of human capital theory and economic growth are the Consolidated Growth models by (Galor, 2000). The idea is to explain economic development with a focus on a (very) long-run economic growth path. In these models, human capital is attributed to a crucial role in the creation of sustainable economic growth.

It is clear in these prevailing literatures that increasing growth of technology in a specific sector of the economy could possibly lead to a greater demand for educated and skilled workforce through training courses. While in the vein Ángel de la Fuente and A. Cicoone (1999) exhibit a much greater role of human capital in explaining productivity differential between countries than in supporting growth. To fill this research gap and to contribute to the current literature, in this study, based on the recent theory of economic growth and human capital development, the study seeks to access the effect of human capital components on the economic growth of Liberia.

In the current literature on empirical findings, as it relates to the accumulation of human capital and it contributes to economic growth, there is empirical evidence and hypothesis tested in investigating the contribution of human capital as a pathway to sustainable economic growth and development. However, many of these pieces of literature have been focused on developing economics rather than least develop economics who has wealth in natural resources but yet lacked the human capital components. That raised the question that can human capital truly affect economic growth in the least developed (third-word) countries with natural (physical) resources but lacks human capital resources? In this way, this study is designed to fill the gap in the prevailing literature to investigate the effect of human capital and contribution to Liberia's economic growth as a least developed country in Sub-Sahara Africa (SSA).

\subsection{Approach of Measuring Human Capital}

The new and standardized approach of measuring human capital are those that are partially acceptable through the conceptual framework of the United Nations Development Program (UNDP) Human Development. The structure of the index is instituted to health care delivery, knowledge or education, and the standard of living with many sub-combined variables such as adult literacy rate, gross enrollment ratio, life expectancy at birth, and GDP per capita in a country or a region. 
The system and approach of measuring human capital were designed in a way to capture the quality aspects of individual (people) life, wealth, and benefits within the economy. Moreover, the standardized measurement of human capital slightly considers the qualitative and gains of human capital from the household level through education, health, fertility, and infant mortality that are engulfed in the framework of the World Bank Human Capital measurement and Index.

\subsection{Liberia's Human Capital Outlook, Index and Ranking}

According to the UNDP Human Development report of 2019 on Liberia's HDI, the value for 2018 is 0.465 that placed the country in the low-ranking human development category and placing it at 181 out of 189 of total countries and territories globally. That shows that the West African nation is still struggling to provide basic education, healthcare delivery, and as well as other social services for her people at all levels.

Between 2000 and 2018, Liberia's HDI value grew from 0.422 to 0.465 , an upsurge of 10.2 showing Liberia's progress in each of the HDI indicators illustrated in table 1. However, between the period 1990 and 2018, Liberia's life expectancy at birth rose to 17.7 years, mean years of schooling increased by 2.1 years, and expected years of schooling contracted by 0.9 years. Liberia's gross national income GNI per capita also increased by 12.7 percent at about the same period 1990 and 2018. 
Table 1: Liberia's HDI trends based on consistent time series data

\begin{tabular}{cccccc}
\hline Year & $\begin{array}{r}\text { Life } \\
\text { expectancy } \\
\text { at birth }\end{array}$ & $\begin{array}{c}\text { Expected } \\
\text { years of } \\
\text { schooling }\end{array}$ & $\begin{array}{r}\text { Mean } \\
\text { years of } \\
\text { schooling }\end{array}$ & $\begin{array}{c}\text { GNI } \\
\text { per capita } \\
\text { (2011 PPP\$) }\end{array}$ & HDI value \\
\hline 1990 & 46.0 &.$\cdot$ & 2.6 & 923 &.$\cdot$ \\
1995 & 48.3 &.. & 3.1 & 261 &.. \\
2000 & 51.7 & 10.5 & 3.5 & 1,209 & 0.422 \\
2005 & 55.4 & 10.0 & 3.8 & 889 & 0.417 \\
2010 & 59.6 & 9.5 & 4.1 & 1,020 & 0.441 \\
2015 & 62.3 & 9.6 & 4.4 & 1,137 & 0.463 \\
2016 & 62.8 & 9.6 & 4.5 & 1,091 & 0.463 \\
2017 & 63.3 & 9.6 & 4.7 & 1,085 & 0.466 \\
2018 & 63.7 & 9.6 & 4.7 & 1,040 & 0.465 \\
\hline
\end{tabular}

Source: United Nations Human Development Report of 2019 computed by author

According to World Bank, the plan for Africa Human Capital development is that for all countries, the key to success in an increasingly globalized and digital economy is ensuring that people have the talents and potentials to take advantage of economic opportunities and be fruitful. The current World Bank's new Human Capital Index (HCI) measures the potential productivity of Africa's next generation.

Africa's HCI score account for 0.4 compared to the global average of 0.57 . That is, under certain circumstances, babies born in Sub-Sahara Africa today will be only $40 \%$ as productive when they grow up as they could be if they had finished training and healthy enough (as determined by the index). It has a direct effect and implication on the overall wellbeing not only of people and families but also the whole economies of the continent on a larger scale.

Those countries placed at the bottom of the index like Mali, Niger, South Sudan, Chad, and Liberia will register the heaviest foregone income and be left further behind in the wakeup of the global economy.

At the same time, countries with significantly developed human capital on the continent can enjoy quite a series of benefits such as reduced poverty gap, increased employment opportunities for the youth, equitable income and wealth distribution, gender 
equality, and sustainable economic growth rate. On the contrary, countries with poor human capital development like Libera and those countries beneath can experience low life expectancy and experience high mortality rates.

Liberia as a low-income country in West Africa, to develop her human capital and close on these gaps to achieve some level of economic growth continue to strive on public policy measures to embark on some educational programs by both past and present leadership had failed on, but these have only served as channels for the corrupt elect-political leaders and their allies to steal public resources and to enrich themselves at the expense of the minority.

The Liberian education system is still undergoing an institutional transformation at all levels and, there is more work that needs to be done due to the effect of the civil unrest covering the period between 1989-2003. Since then, the country continues to make efforts in rebuilding and strengthening its human capital capacity through the provision of affordable education. When the nation confronted the deadly EBOLA pandemic in 2014, many lives were taken away. Approximately 15,000 plus Liberians died at the same time thousands went jobless and unemployed. Still then, the country remains committed through its governments in embarking on intensive efforts at post-war and post Ebola development challenges and to hooping her people for a brighter future.

The government of Liberia commitment is best outlined in the Poverty Reduction Strategy (PRS) 2008-2012, which prioritizes four pillars of activity: (1) enhancing national security, (2) revitalizing key sectors of the economy, (3) strengthening administration and improving on the rule of law, and (4) enhancing infrastructure development and fulfilling basic social services, including education (GoL, 2008).

Due to these circumstances and among others like the current COVID-19 health care crisis, the standard of education in Liberia and the strength of public health remain very poor while the shortage of qualified and innovative teachers in primary and secondary institutions is lacking. Given the high prospects to achieving economic growth in Liberia which human capital development may be the way-out, a modern and digitalized education system will be a priority. Also, well-educated and career-driven teachers in the classroom, and a real-time health care delivery system may help Liberia to overcome some of these goals and meet her potential in the long-run. The contribution of the real-time health care system and modern 
education system put in place could serve as a major component of human capital development for Liberia need not be ignored.

In Sub-Sahara Africa (SSA), the account for human capital remains a major challenge of which related to access to essential services. Government public spending hobbit in sectors that support the attainment of human capital is extremely low in Liberia. For example, the highest expenditure recorded on health care for the year 2015 is $8 \%$. While $2 \%$ was accounted for in (2001, 2002 and 2003) with 3\% for the year 2000. Figure 1 also displaced the full version of regions and their HCI scores with Liberia among the lowest with in the "World Bank Africa Human Capital Plan” and ranking.

Figure 1: Liberia's position in Africa among the lowest with HCI scores

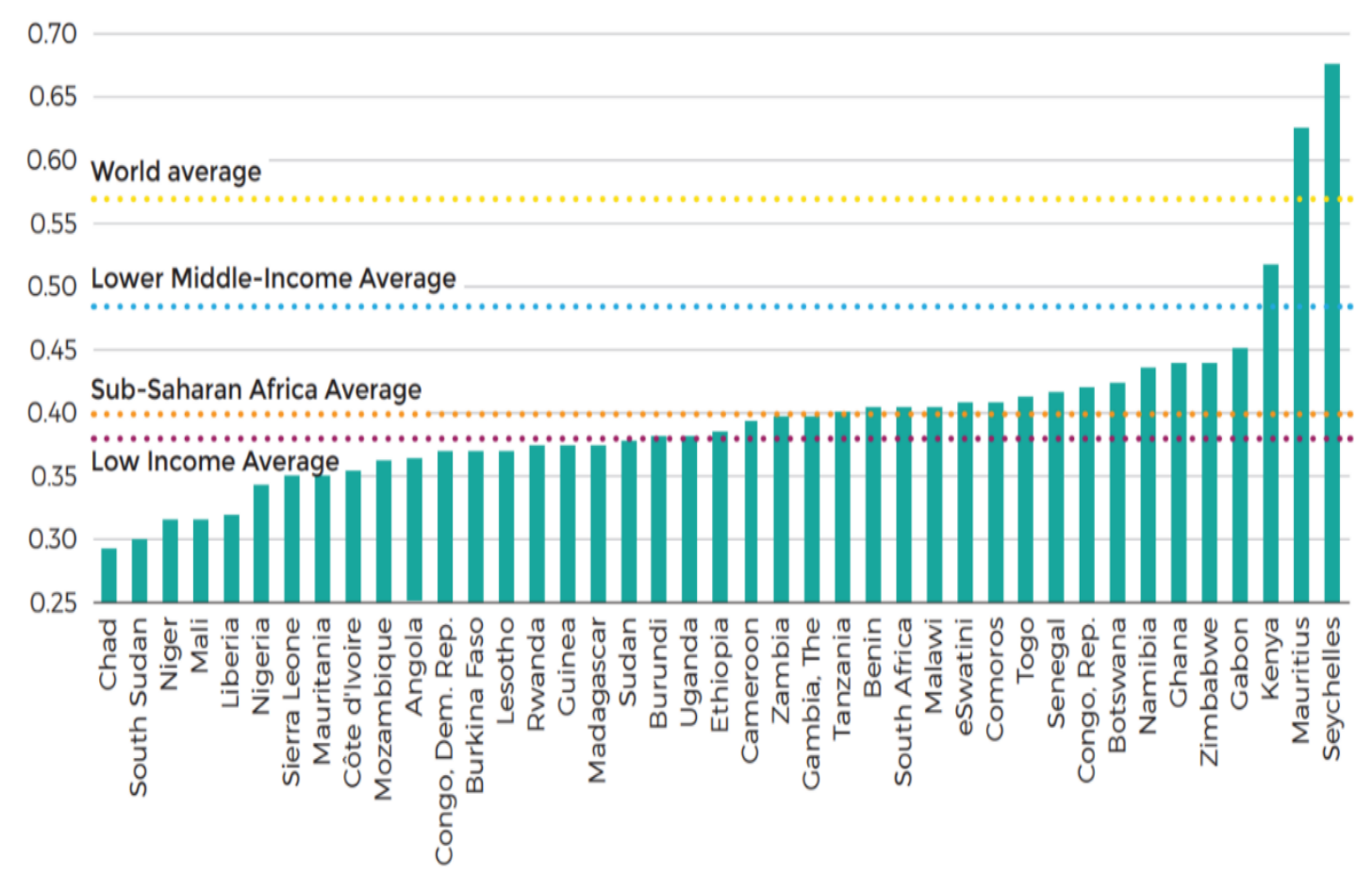

Source: World Bank Africa Human Capital Plan:

\section{Methodology}

The study uses an annual time series data from the period 2000 to 2019 to follow the evolution of human capital in Liberia. The data used in the study is sourced from the World Bank Development Indicators (WBDI) database. The study employed a time series regression model of the Ordinary Least Squares (OLS) technique to analyze the effect of human capital 
on economic growth using macroeconomic indicators such as Health, Life Expectancy at Birth (LIFE_EXP), Total Labor Force (LABOR), Population (POP) growth rate, and foreign AID on the Gross National Income (GNI_PPP) of Liberia. In analyzing the data set on the selected variables, some subsequent tests were employed. First, performing a unit root test for stationary at "level" and then "1st difference", while allowing EViews-7 statistical tool to automatically select Schwarz Info Criterion with maximum legs of 4 to obtain ADF (Augmented Dickey-Fuller) test.

Table 2: Data Measurement and Sources

\begin{tabular}{|c|c|c|}
\hline Variable & Description and Measurement & Source(s) of Data \\
\hline GNI_PPP & $\begin{array}{l}\text { GNI per capita based on purchasing } \\
\text { power parity (PPP) or (Gross } \\
\text { National Product) }\end{array}$ & $\begin{array}{c}\text { World Bank, World } \\
\text { Development Indicators database }\end{array}$ \\
\hline HEALTH & $\begin{array}{l}\text { Current health expenditure per capita, } \\
\text { PPP (current international \$) }\end{array}$ & $\begin{array}{c}\text { World Bank, World } \\
\text { Development Indicators database }\end{array}$ \\
\hline LIFE_EXP & Life Expectancy at Birth & $\begin{array}{c}\text { World Bank, World } \\
\text { Development Indicators database }\end{array}$ \\
\hline LABOR & Total Labor Force & $\begin{array}{c}\text { World Bank, World } \\
\text { Development Indicators database }\end{array}$ \\
\hline POP & $\begin{array}{l}\text { Annual population growth } \\
\text { rate }\end{array}$ & $\begin{array}{c}\text { World Bank, World } \\
\text { Development Indicators database }\end{array}$ \\
\hline AID & $\begin{array}{l}\text { Foreign aid was proxied by } \\
\text { ratio of official aid and other } \\
\text { development assistance }\end{array}$ & $\begin{array}{c}\text { World Bank, World } \\
\text { Development Indicators database }\end{array}$ \\
\hline
\end{tabular}

\subsection{Model presentation}

We formulate the equation as:

$\hat{\mathrm{Y}}_{\mathrm{t}}=\mathrm{mx}+\mathrm{b}+\varepsilon_{t}$

Where: $\hat{\mathrm{Y}}_{t}$ : Dependent variable, $X_{t}$ : Independent variable, $b=$ Constant term, $t=$ Time trend $\varepsilon_{t}:$ is the error term, which is the difference between the actual value of a dependent variable and its predicted value. 
Econometrically, the model for this research analysis will be stated as;

$\hat{\mathrm{Y}}=\beta_{0}+\beta_{1} \mathrm{Xt}+\beta_{2} \mathrm{Xt}+\beta_{3} \mathrm{Xt}+\beta_{4} \mathrm{Xt}+\beta_{5} \mathrm{Xt} \ldots . \varepsilon_{t}$

Where: $\beta_{0}$ is known as the Intercept while $\beta 1, \beta_{2} \ldots$ and $\beta_{5}$ are explanatory variables with $\hat{Y}$ known as the Coefficients. Thus; $\hat{Y}=$ GNI_PPP, $\beta_{0}=$ Intercept, $\beta_{1}=$ HEALTH $_{t}, \beta_{2}=$ LIFE_EXP $_{t}$ $\beta_{3}=\mathrm{LABOR}_{\mathrm{t}}, \beta_{4}=\mathrm{POP}_{\mathrm{t}}, \beta_{5}=\mathrm{AID}_{\mathrm{t}}, \varepsilon_{\mathrm{t}}=$ Error term

The above equation can be expressed in a linear function given an empirical version of the research model as: GNI_PPP ${ }_{t}=\beta_{0}+\beta_{1} \mathrm{HEALTH}_{\mathrm{t}}+\beta_{2} \mathrm{LIFE}_{-} \mathrm{EXP}_{\mathrm{t}}+\beta_{3} \mathrm{LABOR}_{\mathrm{t}}+\beta_{4} \mathrm{POP}_{t}+$ $\beta_{5} A I D_{t}+\varepsilon_{t}$

\section{Empirical Results Presentation and Discussion of Findings}

\subsection{Descriptive statistics}

The Multiple Regression Model was run using E-Views7 to determine the effects of Health, Life Expectancy, Total Labor Force, Population (POP) and foreign AID on the Gross National income (GNI_PPP) of Liberia from the period 2000 to 2019. In this multiple regression model, GNI per capita income is used as a dependent variable in the study, whereas Health, Life Expectancy, LABOR, Population growth rate (POP), and foreign AID are defined as independent variables or explanatory variables. In other to estimate the effect of the variables on the gross national product of Liberia, the Multiple Regression Model is applied. See the Descriptive Statistics of the variables in Table 3 below.

Table 3: Descriptive Statistics

\begin{tabular}{lcccccc}
\hline & GNI_PPP & HEALTH & LIFE_EXP & LABOR_- & POP & AID \\
\hline Mean & $3.64 \mathrm{E}+09$ & 7.519334 & 57.93411 & 1605321. & 15.11439 & $5.79 \mathrm{E}+08$ \\
Median & $3.29 \mathrm{E}+09$ & 8.390221 & 58.60000 & 1580920. & 15.11850 & $5.51 \mathrm{E}+08$ \\
Maximum & $6.47 \mathrm{E}+09$ & 10.28979 & 63.29500 & 2106396. & 15.36355 & $1.42 \mathrm{E}+09$ \\
Minimum & $1.78 \mathrm{E}+09$ & 2.756326 & 51.73400 & 1214647. & 14.86229 & 38480000 \\
Std. Dev. & $1.46 \mathrm{E}+09$ & 2.456783 & 3.835525 & 284023.3 & 0.164969 & $4.38 \mathrm{E}+08$ \\
Skewness & 0.484156 & -1.028778 & -0.244185 & 0.269955 & 0.003387 & 0.392662 \\
Kurtosis & 1.931469 & 2.550820 & 1.705752 & 1.804368 & 1.606925 & 2.004516 \\
& & & & & & \\
Jarque-Bera & 1.559541 & 3.326476 & 1.435188 & 1.290778 & 1.455527 & 1.205791 \\
Probability & 0.458511 & 0.189524 & 0.487925 & 0.524458 & 0.482988 & 0.547225 \\
& & & & & & \\
Sum & $6.55 \mathrm{E}+10$ & 135.3480 & 1042.814 & 28895773 & 272.0591 & $1.04 \mathrm{E}+10$ \\
Sum Sq. & & & & & & \\
Dev. & $3.62 \mathrm{E}+19$ & 102.6083 & 250.0913 & $1.37 \mathrm{E}+12$ & 0.462653 & $3.26 \mathrm{E}+18$ \\
& & & & & & \\
\hline
\end{tabular}




\begin{tabular}{lcccccc}
\hline Observations & 18 & 18 & 18 & 18 & 18 & 18 \\
\hline
\end{tabular}

Source: Author's Computation using EViews Version 7.

The table showing the descriptive statistics also contains the mean, median, maximum, minimum, and standard deviation for the total of 18 observations covering the period 2000 to 2019. The table displaced key values/outputs like the probability, Skewness, Kurtosis, JarqueBera the sum, and the Sum Sq. Dev.

\subsection{Interpreting Regression Coefficients for Linear Relationships}

Applying the Ordinary Least Square (OLS) technique to the variables used in the study, the summary statistics of the test showed that the model of the study is well-tailored, and that the variables are statistically significant. The independent variables in the model explain $95.51 \%$ best fit the model of the dependent variable, therefore, we say that our model is statistically significant. The p-value is less than the significant level of 0.5 , so our sample data prove enough evidence to reject the null hypothesis for the entire population. Our data favor the hypothesis there is a non-zero correlation.

The changes in the independent variable are associated with changes in the dependent variable at the population level. The sign of our regression coefficient in Table 4 tells us whether there is a positive or negative correlation between each of the dependent variables. Our negative coefficient of our explanatory variables HEALTH, LIFE_EXP, and foreign AID suggests that as the independent variable increases, the dependent variable tends to decrease. The coefficient estimation predicates the mean of the "Y" variable changes given a one-unit shift in the explanatory variable while holding other variables in the model constant. Our explanatory variable population (POP) has a direct link and association with gross national income (GNI_PPP). The coefficient of the constant variable recorded $-3.18 \mathrm{E}+11$ indicating a negative relationship between the constant parameter and the Gross National Income (GNI_PPP) level.

Although, the constant parameter has no significant effect on the model rather than reflecting the value of GNI when other independent variables are held constant, see Table 4. The R-squared value in our linear regression models also shows a goodness-of-fit in our prediction. Our regression summary, also flagged out the percentage of the variance in the dependent variable that the independent variables explain jointly. The R-squared value 
measures the strength of the relationship between our model and the "Y" variable. Our Rsquared (R2) explains $95 \%$ strength of the variance in the dependent variable goodness-of-fit.

Table 4: Ordinary Least Squares (OLS) Summary

\begin{tabular}{ccccc}
\hline \hline \multicolumn{1}{c}{ Variable } & Coefficient & Std. Error & t-Statistic & Prob. \\
\hline C & $-3.18 \mathrm{E}+11$ & $8.62 \mathrm{E}+10$ & -3.689442 & 0.0027 \\
HEALTH & -41311534 & 88095563 & -0.468940 & 0.6469 \\
LIFE_EXP & $-6.44 \mathrm{E}+08$ & $3.42 \mathrm{E}+08$ & -1.883447 & 0.0822 \\
POP & $2.38 \mathrm{E}+10$ & $6.97 \mathrm{E}+09$ & 3.412064 & 0.0046 \\
AID & -0.057710 & 0.307634 & -0.187593 & 0.8541 \\
\hline \hline R-squared & 0.955144 & Mean dependent var & $3.64 \mathrm{E}+09$ \\
Adjusted R-squared & 0.941343 & S.D. dependent var & $1.46 \mathrm{E}+09$ \\
S.E. of regression & $3.53 \mathrm{E}+08$ & Akaike info criterion & 42.43431 \\
Sum squared resid & $1.62 \mathrm{E}+18$ & Schwarz criterion & 42.68164 \\
Log likelihood & -376.9088 & Hannan-Quinn criter. & 42.46841 \\
F-statistic & 69.20475 & Durbin-Watson stat & 1.119874 \\
Prob(F-statistic) & 0.000000 & & & \\
\hline \hline
\end{tabular}

Source: Author's Computation using EViews Version7.

Table 4: contains the summary statistics of the regression output and highlighting the coefficients, the significance tests, and the $\mathrm{R}^{2}$ statistic. In other words, the independent variables (GNI_PPP) predict the dependent variables better than just predicting the mean for everything.

\section{Discussion and Conclusion}

This study empirically investigated the effect of human capital on economic growth in Liberia. Human capital accumulation and its effects on economic growth was the main hypothesis that was investigated and tested in this study. To assess the hypothesis empirically, the study employed an Econometrics model while combining endogenous growth variables to test the effect of the variables. The empirical analysis was estimated by using a time series data technique of the Ordinary Least Square model on a set of variables from the period of 2000 to 2019. The overall evidence obtained from the study proves that population growth rate can account for human capital accumulation and contribution to economic growth positively and statistically. 
It implies that as the population increases and is supported through the provision of intensive formal education (average total years of schooling) in a society, it enables the accumulation of human capital through learning. It supports the idea that countries with a youthful population growth rate can finance human capital by investing in tertiary and holistic education that could benefit the people in the long run. Moreover, the inclusion of the Population (POP) growth rate in the model signifies the overall quality of the labor force in the Liberian economy, and the result is statistically significant. Based on our result, we can also say that the present effect of human capital in the economy is the outcome of present performance and that the most significant and historical factor is the outcome of the current happening.

The regression Coefficient output of Life Expectancy at birth, foreign AID and government expenditure on HEALTH in the model are negative and statistically insignificant and that AID is not a way out for Liberia, but to invest in adequately in health care, education, and the training of people. The future of human capital accumulation and its contribution to economic growth in Liberia as a least developed country is still lacking, and therefore, economic growth and development in the long-run could take a downward turn if policymaker (s) failed to act, particularly in prioritizing health care and education.

We can conclude that the clear evidence that investments in people (e.g., education, training, health) could serve as a tool and a pathway to long-run economic growth. Health care, education, and population growth rate are joint investments that may offer scope for a more integrated policy approach to empower the total workforce. The endogenous growth model and theories have claimed that education has a positive effect on economic growth and that has been proven in this study. It shows that enrolment rates in school and the overall education of an individual in a society can serve as a valid indicator (variable) for capturing human capital, and calls for more investment in the quality aspects of health and education. Based on the study findings, there is a need for a strong policy measure to be taken, and that has provided some key policy advice for decision-maker making purposes. 


\section{Recommendation for Policy Action}

The total workforce in the form of human capital can be considered as one of the most important assets that every country has. To meet the growing demand for modern age technology and advanced tools, people need to be trained and well skill in a way that will enable them to handle and operate advanced tools and it can only be possible with the attainment of human capital in the economy. Although technology on one hand is gradually replacing the labor-force-in many advanced countries, but I believe human capital resource in every country is the framework and the building block of every nation's progress. The study proposed the following recommendation but not limited to:

- To compete with the advancement in technology, there is a need for a skilled workforce especially in some functional areas which could be filled through the means of human capital. That is, the government should invest more money in education, health care as essential elements of human capital attainment.

- Supporting reforms that are in the interest of human accumulation and allocate more funding to support programs and invest in the training of people. This could be a great instrument in helping the government to meet its set objectives at the same time empowering a lifelong workforce within the economy.

- To make use of domestic resources while at the same time, demonstrating transparency and accountability when spending taxpayer's money. Since it was noticed that government expenditures on health care delivery and services have no effect and statistically insignificant in this study, it is advisable that the Liberian government particularly focus on consolidating and ensure increased budgetary allocation to the health care sectors. By doing so will help protect the workforce from health threats since those are the main valuable assets of the nation.

- Also, there is a need for the government to revitalize the education sector, through effective and transparent spending, to create a lifelong investment in the youth as they grow up to become impactful in society and strengthen the human capital component and build up the workforce or the overall labor-force in the economy. All these efforts would be useless if 
funds are mismanaged and corruption in these institutions is not minimize. To have these in effect, the government must make use of technology, research, and development as leverage to close the human capital gaps in the sectors.

\section{Research Limitations}

Although there are other key variables that the study may have included in the model for robust results due to the lack of data for some important indicators and therefore it limits the research to those variables with data access. That could have predicted a better outcome of the study by increasing the sample size. Moreover, from a geographical standpoint, the lack of previous studies on the chosen topic is very difficult to find. Statistically, the tests failed to identify some important relationships or connections among the variables due to the small sample size. To address this problem in future research and to build on this study, it is necessary that one base the same study on a larger sample size to end up with more accurate results.

Lastly, to flag that I don't have long years of experience in writing scientific papers or discussing complex economic issuers and analysis that's why the depth and scope of this study may be limited as compared to scholars with a lot of years and expertise in the field.

\section{Disclosure Declaration}

The authors declare no conflicts of interest regarding the publication of this paper.

\section{Acknowledgments}

I would like to thank Prof. Li Ziyu, Ph.D. of Shanghai Maritime University School of Economics and Management for the mentorship and professional advice at the time of conduction this research. And to my good friend Mr. Samukai M. Sarnor, thanks for the peer guide.

\section{Availability of data and materials}

The data and materials presented in this study were generated from the World Bank Development and online Indicators database and reorganized by the author. Other materials such as significant figures were cited from previously published papers. The sample of the data set used in the study for the period under review (2000-2019) is also included in the appendix section. Although the authors would have preferred using first-hand country data in this study for a robust result. The lack of data for some indicators/variables also limits the 
research to those variables available with secondary data access. Moreover, from a geographical or a regional standpoint, the availability of previous studies on the chosen topic is lacking. These and many others limit the sample size of the study.

\section{Funding}

There was no funding provided for the publication of this paper.

\section{Authors' Contributions}

The author collected data from the World Bank Development and online Indicators database and reorganized the data for analysis. The author developed an Econometric model and employed a time series regression model of the Ordinary Least Squares (OLS) technique to analyze the effect of human capital on economic growth using macroeconomic indicators. Prof. Li Ziyu, Ph.D. of Shanghai Maritime University School of Economics and Management acknowledged the content of the study. This paper is also part of a Master thesis by Faliku S. Dukuly, (first author) and Dr. Kun Huang, (second author) who helped significantly to supervised the work. 


\section{References}

Acemoglu, D. a. (2012). What Does Human Capital Do? Review of Golding and Katz's the Race between Education and Technology. Journal of Economic Literature 50 (2), 426463.

Babini, A. M. (1991). Convergence and Divergence of Education Systems in Today's World. Prospects, 21, 330-39.

Bank, W. (2018). Learning to realize education's promise -World Development Report 2018. World Bank Development Index.

Barro, R. (1991). Economic Growth in a Cross Section of Countries. Quarterly Journal of Economics, 106(2), 407-443.

Becker, G. S. (1964). Human Capital: A Theoretical and Empirical Analysis with Special Reference to Education. University of Chicago Press.

Berger, N., \& Fisher, P. (2013). A Well-Educated Workforce is Key to State Prosperity. gEconomic Policy Institute, 3. https://files.epi.org/2013/A\%20welleducated $\% 20$ workforce $\% 20$ is $\% 20$ key $\% 20$ to $\% 20$ state $\% 20$ prosperity.pdf

Ciccone, A. G. (1999). Capital, Wages and Growth: Theory and Evidence. Centre for Economic Policy Research Paper No. 2199.

De La Fuente Á, D. A. (2000). A Human capital in growth regressions: how much difference does data quality make? Economic Department Working Paper No262: OECD.

Demeulemeester, J.-L. A. (2011). Education and Growth: What Links for Which Policy? Historical Social Research, 36 (4): 323-346.

Elena P. (2015). The Impact of Human Capital on Economic Growth. Procedia Economics and Finance, Volume 22, 2015, Pages 184-190, ISSN 2212-5671, https://doi.org/10.1016/S2212-5671(15)00258-0. 
Fashina, O. A. (2018). Foreign aid, human capital and economic growth nexus: Evidence from Nigeria. Journal of International Studies, 105. Retrieved from https://www.researchgate.net/publication/326341035_Foreign_aid_human_capital_a nd_economic_growth_nexus_Evidence_from_Nigeria

G, M. N., D, R., \& Weil D.N. (1992). Contribution to the Empirics of Economic Growth. The Quarterly Journal of Economics, 107, No. 2, 407-437.

Galor, O. a. (2000). Population, Technology, and Growth: From the Malthusian Regime to the Demographic Transition . American Economic Review 90: 806-28.

GoL. (2008). Liberia Poverty Reduction Strategy (PRS) 2008-2012,. Monrovia: Republic of Liberia.

Goldin, C. (n.d.). Human Capital. National Bureau of Economic Research. Retrieved from https://scholar.harvard.edu/files/goldin/files/human_capital_handbook_of_cliometric s_0.pdf

Hadir, M. A. (2015). Human Capital Development and Economic Growth in Morocco.

Haupert, C. D. (2014). Handbook of Cliometrics. Claudia Goldin Department of Economics Harvard University and the National Bureau of Economic Research.

Hippe, C. D. (2019). The long-run impact of human capital on innovation and economic development in the regions of Europe. Applied Economics, 51:5, 542-563,. doi:10.1080/00036846.2018.1495820

Hippe, R. (2014). Human Capital and Economic Growth: Theory and Quantification. Economies Et Sociétés, AF 49.

Horwitz, F. (2005 ). HR CAN Competitiveness advance. Executive Business Brief, 10, 50-52. 
J., M. (1995). Economic Development, Growth of Human Capital, and the Dynamics of the Wage Structure. Discussion Paper Series No. , (September), Columbia University, 38.

Jones, C. I. (1997). Convergence Revisited. Journal of Economics Growth, 2, 131-153.

Love, H. (2020). Looking in the sky. Early JR, 50. Retrieved from www.coconet.com

Lucas, R. E. (1988). On the Mechanics of Econimic Development. Journal of Monetary Economics, 3-42.

Luqman, M. H. (2014). The contribution of international trade to economic growth through human capital accumulation: Evidence from nine Asian Countries. Cogent Economics \& Finance, 11. doi:http://dx.doi.org/10.1080/23322039.2014.947000

Mankiw, G. D., \& David Wei. (1992). A Contribution to the Empirics of Economic Growth. Quarterly Journal of Economics, 107, 407-437.

Neamtu, D. M. (2015). Education, the economic development pillar. The 6th International Conference Edu World 2014 "Education Facing Contemporary World (p. 415). Suceava 720229, Romania: ELSEVIER.

Nelson, R. R. (1966). Investment in Humans, Technological Diffusion, and Economic Growth. American Economic Association Papers and Proceedings 56 (1-2): 69-75.

Ogunleye, O. O. (2017). HUMAN CAPITAL DEVELOPMENT AND ECONOMIC GROWTH IN NIGERIA. IJRDO-Journal of Business Management , 18.

Pelinescua, E. (2014). The impact of human capital on economic growth. 2nd International Conference 'Economic Scientific Research - Theoretical, Empirical and Practical Approaches', ESPERA 2014, 13-14 November 2014 (pp. 22 ( 2015 ) 184 - 190). Bucharest, Romania: Procedia Economics and Finance.

Pistorius, C. (2004). The Competitiveness and innovation Elektron. 21, No.3. 
Pritchett. (1997). Divergence, Big Time,. Journal of Economics Perspectives, 11(3), 3-18.

Riley G. (2012). Economic Growth - The Role of Human \& Social Capital, Competition \& Innovation, $\quad$ Retrieved $\quad$ April $\quad 16, \quad 2014, \quad$ from http://www.tutor2u.net/economics/revisionnotes/

Romer, P. (1990). Human capital and growth: theory and evidence . Carnegie Rochester Conference Series on Public Policy, 32, pp.251-286.

Romer, P. (1993). Idea Gaps and Object Gaps in Economic Development. Journal of Monetary Economics, 32, 543-573.

Romer, P. M. (1986). Increasing Returns and Long-Run Growth. Journal of Political Economy 94 (5): 1002-1037.

Schultz, T. W. (1975). The Value of the Ability to Deal with Disequilibria. Journal of Economic Literature 13 (3): 827-846.

Siggel, E. (2000). Uganda's policy Reforms, Competitiveness and regional integration industry: A comparison with Kenya. African Economic.

World Bank Africa Human Capital Plan:

http://pubdocs.worldbank.org/en/910151554987573474/HCP-Africa-Screen-inEnglish.pdf 
Figures

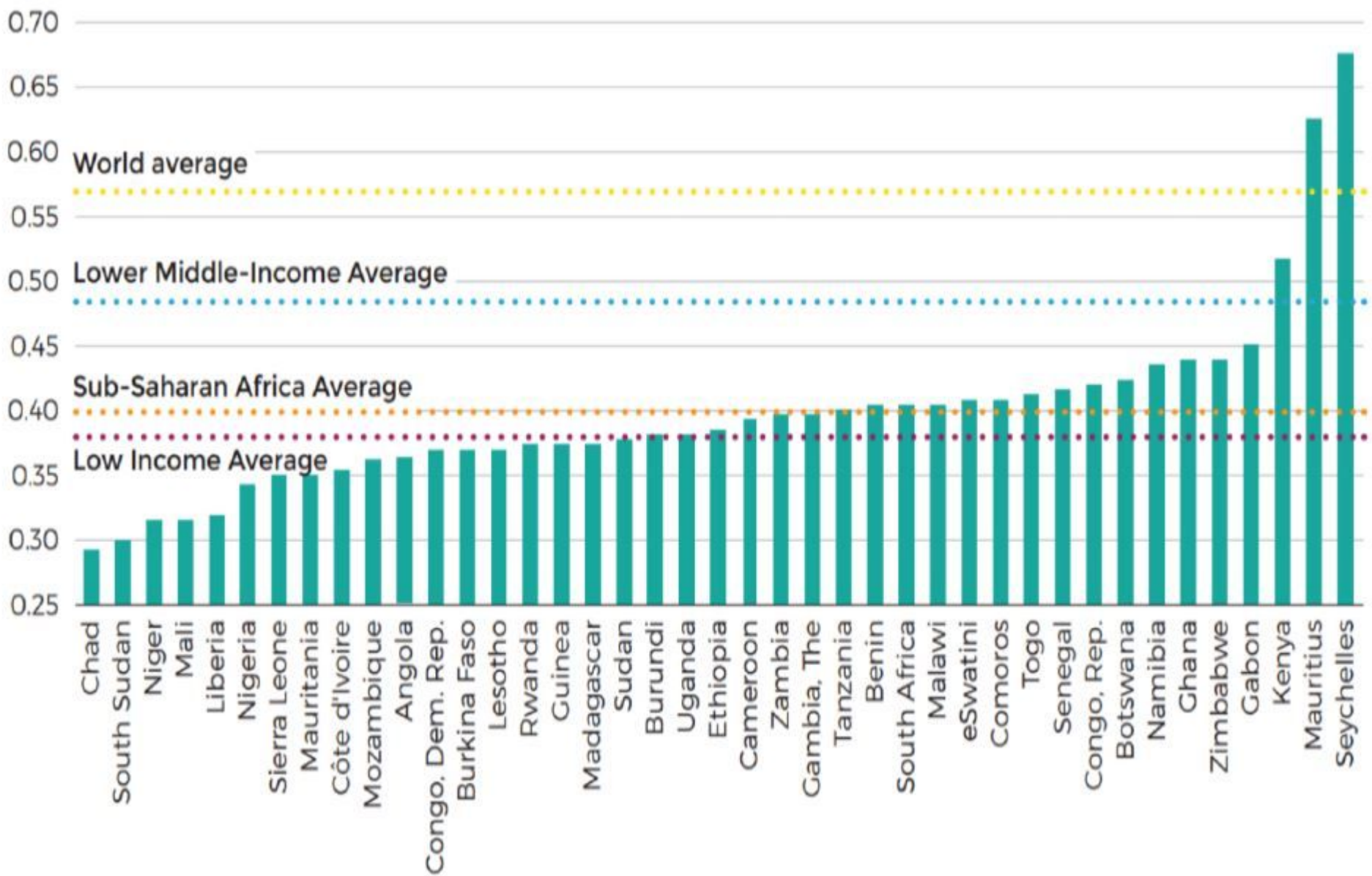

Figure 1

Liberia's position in Africa among the lowest with $\mathrm{HCl}$ scores. Source: World Bank Africa Human Capital Plan: 